\title{
Analisa Gangguan Medan Magnet Kereta Api Listrik terhadap Pengamatan Geomagnet
}

\author{
Syamsul Hidayat Lubis ${ }^{1, \dagger}$, Sutisno $^{1}$, Litanya Oktonovrilna ${ }^{2}$ \\ ${ }^{1}$ Program Studi Fisika, Fakultas Sains dan Teknologi, Universitas Islam Negeri Syarif Hidayatullah Jakarta, \\ Jalan. Ir. H. Djuanda No.95, Cempaka Putih, Ciputat, Kota Tangerang Selatan, Banten 15412, Indonesia \\ ${ }^{2}$ Stasiun Geofisika Kelas 1 BMKG Tangerang \\ †'syamsul.hidayatlubis@gmail.com
}

\begin{abstract}
Abstrak. Peristiwa gangguan medan magnet yang dihasilkan oleh kereta api listrik DC (Direct Current) tidak hanya berasal dari arus motor traksi, namun juga dari arus kebocoran ke tanah, hal ini menjadi permasalahan besar bagi pengamatan geomagnet dan penelitian elektromagnet lainnya. Perhitungan secara teoritis yang memungkinkan adanya pendekatan kuantitatif dari dampak magnetik dari kereta api listrik DC termasuk arus bocor ke tanah dapat di jelaskan pada penelitian ini. Validitas dari model teoritis dapat diverifikasi dengan perngamatan langsung di titik lokasi dari stasiun Tangerang sampai dengan stasiun Duri. Pengamatan gangguan medan magnet kereta api listrik ini menggunakan sensor magnet tipe LEMI - 018 MAGNETOMETER yang berada pada stasiun pengamatan Geofisika klas 1 BMKG (Badan Meteorologi Klimatologi dan Geofisika) kota Tangerang. Perhitungan numerik menggunakan metode ARIMA (Auto Regression Moving Average) pada software MATLAB mengindikasikan tingkat gangguan maksimum sebesar $27 \mathrm{nT}$ pada komponen F. Titik koordinat sensor, posisi gardu listrik dengan kereta, dan arus traksi serta arus kebocoran ke bumi menjadi faktor penting dalam penelitian ini.
\end{abstract}

Kata Kunci: Pengamatan Geomagnet, Kereta Api Listrik, Arus Bocor ke bumi, Medan Magnet, Gardu listrik.

\begin{abstract}
Abstrac. The magnetic field disturbance produced by the DC (Direct Current) electric train not only comes from the traction motor current, but also from the leakage current to the ground, this is a big problem for geomagnetic observation and other electromagnetic research. Calculation theoretically that allow the presence of a quantitative approach of the impact of magnetic from the train electricity dc including a current of leaking to the ground will be able to explain it to this research. The validity of the theoretical model can be verified by direct observation at the location point from Tangerang station to Duri station. Observation of this electric train magnetic field disturbance uses magnetic sensor type LEMI - 018 MAGNETOMETER which is located on class 1 Geophysics observation station of BMKG (Meteorology Climatology and Geophysics Agency) of Tangerang city. Numerical calculations using the ARIMA method (Auto Regression Moving Average) in MATLAB software indicate a maximum interference level of $27 \mathrm{nT}$ on component $\mathrm{F}$. The sensor coordinate points, the position of the electrical substation with the train, and the traction flow and leakage current to the earth are important factors in this study.
\end{abstract}

Keyword: Geomagnetic Observation, Electric Railway, Leakage Current to Earth, Magnetic Fields, Electric Substations.

\section{PENDAHULUAN}

Kereta api listrik menghasilkan medan magnetnya sendiri yang disebut medan magnet lokal. perhitungan yang tepat dalam pengamatan geomagnetik dengan peralatan yang cukup baik sangat penting dibutuhkan. Terdapat beberapa contoh sejarah yang berhubungan dengan lokasi pengamatan geomagnet yang perlu dipindahkan lebih jauh dari jalur kereta api listrik DC karena menyebabkan gangguan pengamatan yang signifikan (Nevanlinna, 2004).

Pada prinsipnya, arus traksi yang dibutuhkan untuk menggerakkan kereta harus mengalir pada sirkuit tertutup dengan memberi arus pada kabel atas dan meneruskan keseluruh rangkaian kereta. Medan magnet dihasilkan traksi tersebut dekat dengan jalur lintasan rel kereta cukup signifikan, pada praktiknya kereta mungkin memiliki kontak langsung dengan tanah melalui relnya yang menyebabkan adanya arus bocor menuju bumi. Model yang dipresentasikan pada penelitian medan magnetik yang disebabkan oleh kereta api listrik DC dengan menggunakan hukum biot - savart, rumus ideal mengenai medan magnet tanpa arus bocor dan untuk medan magnet pada arus yang bocor, sehingga medan magnet total pada system kereta api listrik yaitu jumlah kedua medan magnet tersebut (Georgescu, 2002). 
Terjadinya Pertumbuhan penduduk dan pembangunan daerah besar - besaran yang dilakukan oleh pemerintah kota Tangerang menyebabkan adanya gangguan medan elektromagnet yang ditimbulkan oleh aktifitas kelistrikan seperti kereta api listrik dan transformator serta benda kelistrikan lainnya menyebabkan adanya gangguan pengamatan medan magnet bumi. Analisa secara kualitatif dan kuantitatif akan dilakukan pada penelitian ini sehingga model teoritis dari gangguan aktifitas kereta api listrik tersebut dapat ditunjukkan pada pengamatan magnet bumi di Stasiun Geofisika Klas 1 BMKG Tangerang.

\section{LANDASAN TEORI}

\section{Kereta Api Bertenaga DC}

Jumlah Kereta Rel Listrik terus ditingkatkan dan ini harus diimbangi pula dengan peningkatan penyediaan daya pada listrik aliran atasnya. Rangkaian kereta api listrik dapat digunakan untuk perjalanan jarak jauh maupun Commuter line. Dalam beberapa kasus sering disebut sebagai Light Rapid Tansit (LRT) atau Metro maupun Tram ketika beroperasi di jalan. Namun untuk lebih mudah kita akan menyebutnya dengan kereta api listrik (KRL). Lokomotif kereta bertenaga electric - diesel menghasilkan arus listrik pada kereta itu sendiri, atau dengan daya AC (Alternating Current) dimana rektifikasi terjadi dari arus AC ke DC (Direct Current) di kereta.

\section{Sistem Catu Daya}

Pada umumnya arus listrik akan kembali menuju gardu melalui kedua rel atau salah satunya. Kebocoran yang terjadi pada proses kembalinya arus ini menyebabkan permasalahan pada pengamatan geomagnet. Current International Standart (CIS) menentukan nominal tegangan suplai DC sebesar 750, 1500, 3000 V. Dengan daya listrik berkisar $1 \mathrm{MW}$ atau lebih, maka arus traksi berkisar $1000 \mathrm{~A}$ atau lebih. Pada pemukiman padat penduduk jarak antara gardu recifier $\leq 2 \mathrm{~km}$, namun pada sistem "single track" jaraknya mungkin sekitar $20 \mathrm{~km}$ atau lebih (Lowes, 2009).

\section{Sejarah Magnet Bumi}

Minat umat manusia terhadap magnetisme berawal pada sifat tarik menarik dari mineral Lode stone, bentuk magnetik alami. Sering disebut sebagai loadstone sebutan tersebut berasal dari bahasa inggris lama, kata "Load" bermakna "jalan" ataupun "jalur". Loadstone secara harfiah merupakan sebuah batu yang menunjukan arah kepada para musafir (Lowrie, 2007).

Pada abad pertengahan banyak fantasi mengerikan mengenai magnet, namun semua itu dibantah oleh William Gilbert dalam bukunya pada tahun 1600 Monograf De Magnete, yang bisa dibilang merupakan teks ilmiah modern pertama. Pemeriksaan arah bidang dipol pada permukaan bola Lodestone atau "Terella", dan mengaitkannya dengan pengamatan kemiringan yang saat itu telah diukur pada banyak titik dipermukaan bumi. Gilbert mengidentifikasikan gaya dari sumber magnetik yang menyelaraskan jarum kompas seperti bumi itu sendiri, bukan bintang seperti yang diasumsikan sebelumnya. Dia menduga bahwa bumi itu sendiri adalah magnet raksasa.

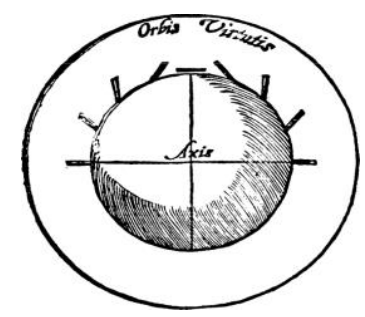

GAMBAR 1. Miniatur bola magnet sebagai bumi

Pada Tahun 1935, Henry Gilibrano yang mempelajari data ini menyadari bahwa medan magnet bumi berubah-ubah seiring dengan waktu. Medan magnetik bumi dapat digambarkan sebagai batang magnet dengan dua kutub yang terletak di dalam bumi tapi tidak tepat ditengah-tengah. Sumbu magnet bumi bergeser sejauh $1.200 \mathrm{~km}$ dari sumbu tengah bumi.

\section{Medan Magnet Bumi}


Bumi berlaku seperti sebuah magnet sferis yang sangat besar dengan suatu medan magnet yang mengelilinginya. Medan itu dihasilkan oleh suatu dipol magnet yang terletak pada pusat bumi. Sumbu dipol ini bergeser sekitar $11^{\circ}$ derajat dari sumbu rotasi bumi, yang berarti kutub utara geografis bumi tidak terletak pada tempat yang sama dengan kutub utara magnetik bumi (Lowrie, 2007).

Medan magnet bumi tergolong lemah, Intensitas maksimum ketika mencapai dekat dengan kutub magnet sekitar $6 \times 10^{-5} \mathrm{~T}$. Instrumen modern untuk menghitung medan magnet disebut dengan magnetometer memiliki sensitifitas sebesar $10^{-9} \mathrm{~T}$, satuan ini disebut nanotesla $(\mathrm{nT})$ dan telah diadopsi dalam geofisika sebagai intensitas medan magnet bumi. Sebagian besar survei geomagnet dilakukan sampai tahun 1970 an menggunakan sistem satuan c.g.s, dimana medan magnet B dihitung dalam satuan Gauss, setara dengan $10^{-4} \mathrm{~T}$. Satuan eksplorasi geofisika kemudian menjadi $10^{-5}$ Gauss, disebut sebagai Gamma $(\gamma)$. Dengan demikian satuan tersebut sama dengan $10^{-9} \mathrm{~T}$ atau nanotesla (nT).

Medan magnet bumi merupakan vektor yang dapat digambarkan pada permukaan bumi dengan tiga komponen ortogonalnya atau komponen magnet $X$ (menunjuk kearah utara geografis), Komponen Y (menunjuk kearah timur) dan komponen Z (arah vertikal kebawah). Dua komponen magnetik X dan $\mathrm{Y}$ dapat digabungkan dapat menghasilkan komponen intensitas medan magnetik $\mathrm{H}$ dengan $\mathrm{H}=$ $\sqrt{\mathrm{X}^{2}+\mathrm{Y}^{2}}$, yang sejajar dengan arah jarum kompas. Dengan menambahkan komponen vertikal $Z$, maka medan magnet total $F$ diperoleh nilai medan magnet komponen $F=\sqrt{X^{2}+Y^{2}+Z^{2}}$. Deklinasi $D$ didefinisikan sebagai sudut antara $\mathrm{H}$ dengan utara geografis dan inklinasi sebagai sudut antara budang horizontal bumi dengan vektor medan magnet $\mathrm{F}$ (Glaßmeier, 2002).

Alternatifnya, elemen geomagnet dapat juga digambarkan dalam koordinat bola. Besar vektor magnet bisa didapatkan dari kuat medan magnet $\mathrm{F}$, dengan deklinasi sebagai sudut antara kutub utara magnetik dan utara geografis dan Inklinasi sebagai sudut dari arah vektor magnet dibawah garis horizontal.

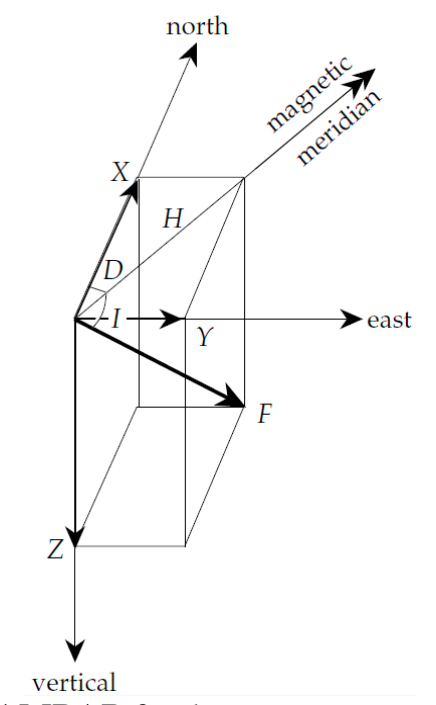

GAMBAR 2. Elemen Magnet Bumi

Bentuk kartesian $(\mathrm{X}, \mathrm{Y}, \mathrm{Z})$ dan koordinat bola $(\mathrm{F}, \mathrm{D}, \mathrm{I})$ dalam elemen geomagnet dapat saling berkaitan dengan persamaan:

$\mathrm{X}=\mathrm{F} \cos I \cos \mathrm{D}$;

$\mathrm{Y}=\mathrm{F} \cos I \sin \mathrm{D}$;

$\mathrm{Z}=\mathrm{F} \sin \mathrm{I}$

$$
\mathrm{D}=\operatorname{acrtan}\left(\frac{\mathrm{X}}{\mathrm{Y}}\right) ; \mathrm{I}=\arctan \left(\frac{\mathrm{Z}}{\sqrt{\mathrm{X}^{2}+\mathrm{Y}^{2}}}\right)
$$

salah satu komponen utama magnet bumi adalah dipol magnet. Dipol tidak selaras dengan poros rotasi bumi karenanya kutub magnetik menyimpang dari kutub geografis. Variasi dengan garis lintang dari besar dan arah yang ideal dari bidang dipol sejajar sepanjang sumbu putar bumi (Milsom, 2003). 


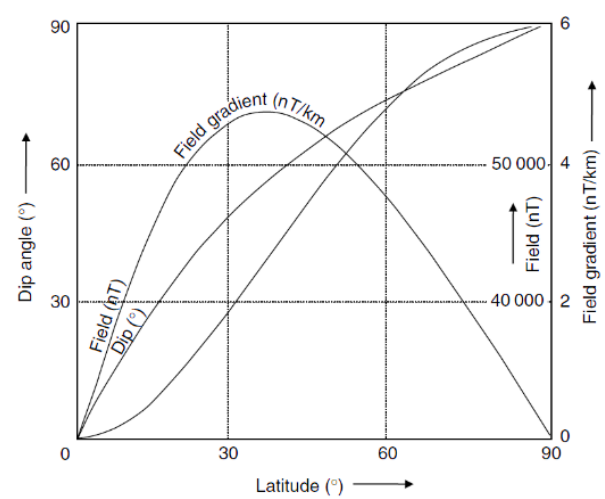

GAMBAR 3. Variasi Intensitas, kemiringan dan gradien sepanjang poros bumi

\section{Gaya Magnetik}

Dasar teori dari metode magnetik adalah gaya coulomb antara dua kutub magnet $m_{1}$ dan $m_{2}$ (e.m.u) yang berjarak $\mathrm{r}(\mathrm{m})$ dalam bentuk berikut:

$$
\vec{F}=\frac{m_{1} m_{2}}{\mu_{0} r^{2}} \vec{r}
$$

Dimana $\vec{F}$ adalah gaya yang bekerja diantara dua magnet dengan kuat medan magnet $m_{1}$ dan $m_{2}$. $\mu$ adalah permeabilitas suatu medium dengan satuan Henry per meter $\left(\mathrm{Hm}^{-1}\right)$. Dalam medium hampa permeabilitas mutlak sama dengan $\mu_{0}$ yang nilainya $4 \pi \times 10^{-7} \mathrm{Hm}^{-1}$. Konstanta $\mu_{0}$ adalah permeabilitas untuk ruang hampa tidak berdimensi.

\section{Hukum Biot-Savart}

Elemen medan magnet $\mathbf{d B}$ dihasilkan oleh elemen vektor arus $I \mathbf{~ d s}$ dari persamaan hukum Biot Savart. Medan magnet yang dihasilkan pada jarak $\mathrm{r}$ dari muatan bergerak q sebesar:

$$
B=\frac{\mu_{0} q(V \times \hat{r})}{4 \pi r^{2}}
$$

Kemudian $r$ merupakan jarak dari muatan terhadap titik medan magnet diukur dan $r$ adalah vektor satuan dengan arah tegak lurus permukaan yang dibentuk perkalian vektor v dan r. Arah daripada garis - garis gaya magnet ditentukan dengan kaidah tangan kanan. Sebuah kawat apabila dialiri oleh arus listrik akan menghasilkan medan magnet yang Garis - garis gayanya berupa lingkaran yang berada di sekitar kawat tersebut. Titik A dengan P didefinisikan dengan a, yang merupakan jarak suatu titik dengan kawat berarus. Persamaan matematis ini dikenal sebagai hukum Biot - Savart. Salah satu contoh penggunaan paling sederhana adalah pada kawat lurus:

Pada gambar diatas jarak antara titik A dengan P merupakan jarak tegak lurus antara kawat dengan titik pengamatan. Kemudian kita bagi prosesnya pada kondisi kawat BA sebagai salah satu kondisi dimana terdapat jarak antara titik pengamatan P dengan kawat arus di titik tertentu, pada kasus ini didefinisikan dengan vektor $r$. Setelah itu bentuk model magnetnya menjadi:

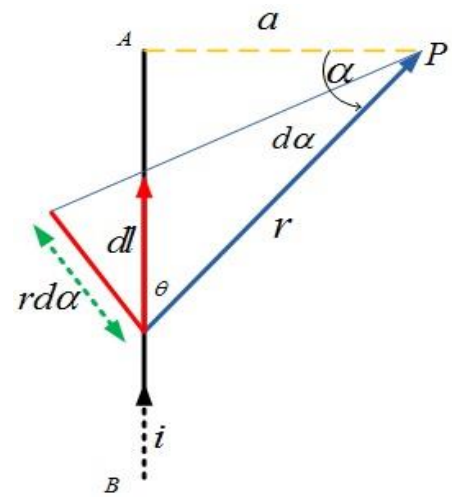

GAMBAR 4. Model magnet Biot - Savart

Kemudian pada gambar diatas ini $\sin \theta=\cos \alpha$. Untuk kawat berarus elemen arus I dl dimasukkan untuk mengganti qv, sehingga diperoleh: 
Subtitusi nilai $\sin \theta$

$$
\begin{aligned}
& \int d_{B}=\int \frac{\mu_{0} \mathrm{I}}{4 \pi} \frac{\mathrm{dl} \times \hat{\mathrm{r}}}{\mathrm{r}^{2}} \\
& \mathrm{~B}_{P}=\frac{\mu_{0} \mathrm{I}}{4 \pi} \int \frac{\mathrm{dl} \sin \theta}{\mathrm{r}^{2}}
\end{aligned}
$$

$$
\begin{gathered}
\sin \theta=\frac{\mathrm{rd} \alpha}{d l} \\
\mathrm{~B}_{P}=\frac{\mu_{0} \mathrm{I}}{4 \pi} \int \frac{\mathrm{dl}}{\mathrm{r}^{2}} \frac{r d \alpha}{d l} \\
\mathrm{~B}_{P}=\frac{\mu_{0} \mathrm{I}}{4 \pi} \int \frac{d \alpha}{r}
\end{gathered}
$$

Subtitusi nilai $\mathrm{r}$ dengan $\cos \alpha=\frac{a}{r}$

$$
\begin{gathered}
\mathrm{B}_{P}=\frac{\mu_{0} \mathrm{I}}{4 \pi} \int \frac{\cos \alpha d \alpha}{a} \\
\mathrm{~B}_{P}=\frac{\mu_{0} \mathrm{I}}{4 \pi \mathrm{a}} \int_{0}^{90} \cos \alpha d \alpha \\
\mathrm{B}_{P}=\left.\frac{\mu_{0} \mathrm{I}}{4 \pi \mathrm{a}} \sin \alpha\right|_{0} ^{90}
\end{gathered}
$$

Besar medan magnet yang dihasilkan oleh setengah kawat yang sangat panjang BA, maka batas $\alpha$ terkecil adalah $\alpha=0$ dan terbesar $\alpha=90$ adalah:

$$
\mathrm{B}_{P}=\frac{\mu_{0} \mathrm{I}}{4 \pi \mathrm{a}}
$$

Jika dianggap panjang kawat tak - terhingga, maka dengan cara ang sama kawat AC pun akan menghasilkan medan magnet yang sama dititik $\mathrm{P}$, oleh sebab itu untuk menghitung besar medan magnet seluruh BAC adalah:

$$
\mathrm{B}_{P}=\frac{\mu_{0} \mathrm{I}}{2 \pi \mathrm{a}}
$$

Pada prinsipnya penyelesaian kasus medan magnet akibat kawat lurus berarus I yang panjangnya berhingga ini sama dengan kasus kawat tak berhingga. Besar medan magnet dititik P apabila kawat tidak sangat panjang seperti:

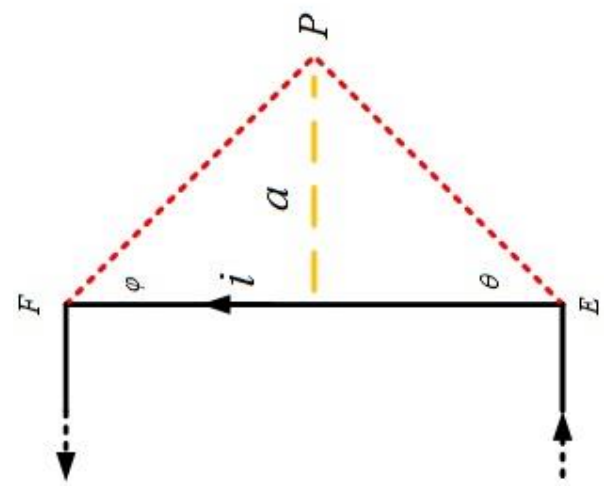

GAMBAR 5 Model magnet Biot - Savart pada kawat panjang terhingga

Maka besar medan magnet pada titik $\mathrm{P}$ adalah:

$$
\mathrm{B}_{P}=\frac{\mu_{0} \mathrm{I}}{4 \pi \mathrm{a}}(\cos \theta+\cos \varphi)
$$

\section{METODOLOGI PENELITIAN}

\section{Tempat Penelitian}

Penelitian ini dilakukan di Stasiun Geofisika Badan Meteorologi Klimatologi dan Geofisika (BMKG) Klas 1 Tangerang Lokasinya berada di Jl. Meteorologi no. 5 Tanah tinggi Tangerang. dengan koordinat $06^{\circ} 10^{\prime} 18^{\prime \prime} \mathrm{LS}$ dan $106^{\circ} 38^{\prime} 46^{\prime \prime} \mathrm{BT}$. 


\section{Bagan Alir Penelitian}

Penelitian ini memiliki beberapa proses, dari pengumpulan data mentah sampai dengan interpretasi data dalam bentuk grafik. Diagram alir dari penelitian gangguan medan magnet kereta api listrik dapat ditampilkan sebagai berikut:

\begin{tabular}{|l|}
\hline - Studi Literatur \\
\hline - Identifikasi Masalah \\
\hline - Observasi Posisi Stasiun \\
\hline - Pengambilan Data \\
\hline - Pengolahan Data Magnetik \\
\hline - Interpretasi Data \\
\hline - Selesai \\
\hline
\end{tabular}

GAMBAR 6. Bagan Alir Penelitian

\section{Waktu dan Tempat}

Penelitian ini dilaksanakan pada:

Waktu : 07 Juni 2017 - Selesai

Tempat :BMKG (Stasiun Geofisika klas 1 Tangerang).

\section{Alat dan Bahan}

Penelitian ini membutuhkan beberapa peralatan pendukung dalam menunjang pengamatan medan magnet diantaranya:

1. Fluxgate Magnetometer LEMI-018

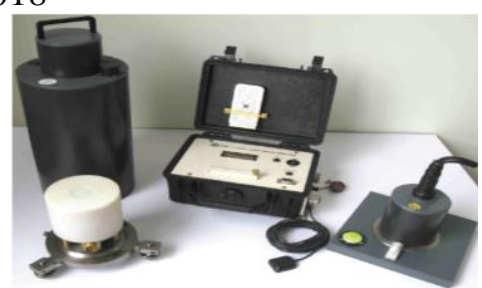

GAMBAR 7. LEMI-018

2. GPS (Global Positioning System)

Adalah sistem satelit navigasi dan penentuan posisi. GPS ini memiliki fungsi untuk menentukan suatu posisi berdasarkan 4 faktor yaitu latitude, longitude, altitude and time.

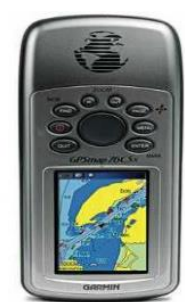

GAMBAR 8. Global positioning system 


\section{Stopwatch}

Untuk mengukur rentang waktu saat pemberhentian kereta di setiap interval lima detik dan disetiap stasiun.

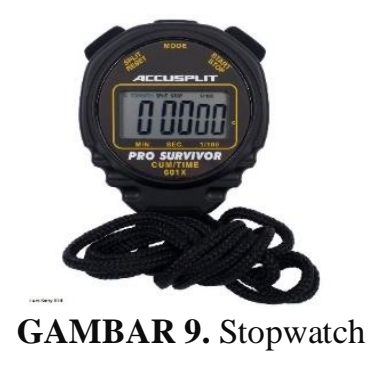

\section{PEMBAHASAN}

\section{Interpretasi Data}

Penelitian ini menyajikan interpretasi data dalam bentuk pendekatan Persamaan biot - savart yang dijelaskan pada bagian sebelumnya dalam penelitian ini dan memungkinkan adanya perhitungan medan magnet yang diciptakan oleh kereta api listrik yang berbeda pengaruhnya pada setiap titik stasiun pemberhentian.

Model Arus kebocoran total nominal pada sistem ini dapat diasumsikan sama dengan 20 A. Namun terkadang lebih dari 50\% dari total arus saat ini mungkin bocor ke tanah. Oleh karena itu, kita membahas komponen medan magnet di lokasi tertentu sebagai fungsi arus bocor total. Model koordinat xy pada tiga stasiun kereta api listrik terdekat dengan sensor magnet di stasiun pengamatan geomagnet BMKG Tangerang dengan titik $\mathrm{P}$ sebagai sensor magnet. Berikut ini adalah model koordinat xy tersebut:

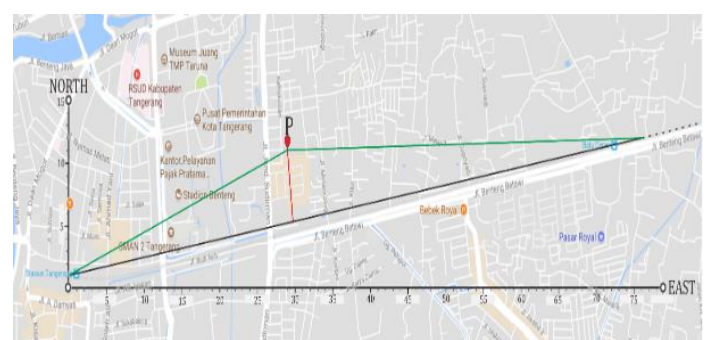

GAMBAR 10. Model koordinat sensor magnet terhadap rel.

Kita akan mempersempit penelitian ini sebagai model Biot - Savart dengan kondisi titik acuan P terhadap kabel listrik terhingga antara stasiun Tangerang dengan Stasiun Batu Ceper. Titik P merupakan acuan pengamatan dengan jarak 340 meter dari rel kereta, kemudian jarak stasiun Tangerang sampai dengan Batu Ceper sekitar 3615 meter. Berikut ini interpretasi data tersebut:

\section{Pengaruh Waktu Perjalanan}

Pengaruh perubahan medan magnet bumi pada pengamatan di stasiun geofisika BMKG Tangerang terhadap waktu perjalanan dalam interval waktu 5 detik keberangkatan kereta dari stasiun Tangerang dimulai pada pukul 13:55:00 WIB sampai menuju stasiun Duri pada pukul 14:16:00 WIB, Grafik pengamatan tersebut diantaranya:

\section{Pengaruh Terhadap Waktu}

Pengamatan magnet bumi dilakukan dengan presisi per satuan waktu. Berikut ini merupakan grafik pengamatan magnetik pada tanggal 7 Juni 2017 selama dua puluh empat jam, variasi magnetik pada komponen $\mathrm{X}, \mathrm{Y}$, dan $\mathrm{Z}$ diantaranya: 


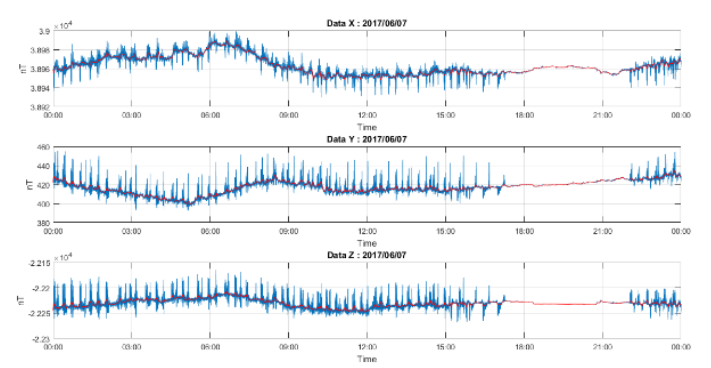

GAMBAR 11. Grafik magnetik komponen X, Y, Z

Kemudian grafik variasi magnetik pada komponen H, F serta sudut Inklinasi dan Deklinasi selama pengamatan magnetik sebagai berikut:

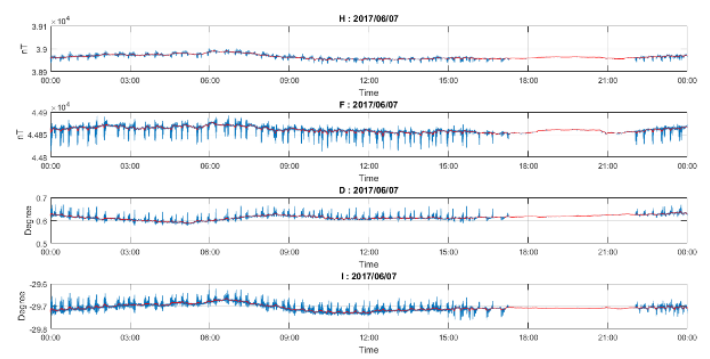

GAMBAR 12. Grafik magnetik komponen H, F, D, dan I

Pengamatan aktifitas matahari seperti yang dikutip pada spaceweather.com pada tanggal 7 Juni 2017 tercatat bahwa tidak adanya bintik hitam atau Coronal Mass Ejection (CME) sehingga gangguan pengamatan dari dari aktifitas medan magnet matahari saat itu sangat kecil.

Aktifitas magnetik bumi bersifat diurnal, karena untuk bagian muka bumi yang terkena matahari akan terpapar gelombang elektromagnet sehingga nilai magnetik bumi pada siang hari lebih besar daripada malam hari. waktu yang tercantum pada grafik diatas merupakan waktu Greenwich sehingga untuk indonesia GMT +7 untuk waktu indonesia bagian barat. Pada komponen X aktifitas medan magnetik bumi berada pada puncaknya pada pukul 12.00 WIB - 13.00 WIB sedangkan untuk nilai medan magnetik minimum terjadi pada pukul $23.00 \mathrm{WIB}-01.00 \mathrm{WIB}$, hal ini menguatkan bahwa nilai maksimum pada komponen X sangat dipengaruhi oleh bagian muka bumi yang terpapar sinar matahari.

Gangguan magnetik akibat dari aktifitas kereta api listrik dapat kita analisa secara lebih spesifik dengan mempertimbangkan bahwa jam operasional kereta api listrik DC dimulai pukul 05.00 WIB 11.00 WIB. Berdasarkan grafik diatas Gangguan medan magnet dimulai pada pukul 05.00 WIB dan berhenti pada pukul $00.00 \mathrm{WIB}$. sensor magnet masih terjadi gangguan satu jam setelah kereta api listrik dimatikan disebabkan karena masih ada induksi medan listrik dari rel dan kabel sehingga masih tercatat oleh sensor magnet.

\section{Ganggguan selama pengamatan}

Data variasi medan magnet akan di smoothing dengan metode ARIMA menggunakan software $M A T L A B$. Berikut ini grafik dari interval gangguan variasi magnetik selama pengamatan pada pukul 13:55:00 WIB sampai dengan 14:16:00 WIB:

\section{Gangguan Komponen F}

Komponen medan magnet $\mathrm{F}$ memiliki nilai gangguan maksimum sebesar 27,75 nT, Kita dapat beranggapan bahwa gangguan medan magnet komponen $\mathrm{F}$ ini mewakili ketiga komponen lain, dapat dijelaskan bahwa adanya arus kebocoran ke bumi yang cukup signifikan. Pada grafik komponen F dapat diperhatikan bahwa gangguan terbesar terjadi ketika rangkaian kereta api listrik bergerak mendekati sensor magnet baik itu dari arah stasiun Tangerang ataupun sebaliknya. 


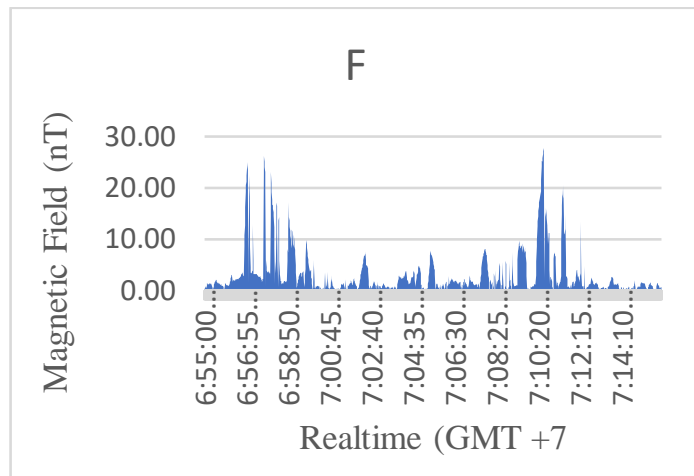

GAMBAR 13. Grafik Gangguan komponen Medan Magnet F

\section{Pembahasan Teoritis}

Hasil perhitungan teoritis menggunakan persamaan rumus Biot - Savart dengan mengguanakan data arus bocor ketanah sebesar $20 \mathrm{~A}$, kemudian interpretasi dibagi menjadi dua bentuk grafik penurunan medan magnet terhadap jarak. Model A merupakan penurunan medan magnet pengaruh jarak sensor terhadap rel kereta api, dengan jarak antara sensor magnet dan rel kereta sejauh 340 meter. Kemudian model B merupakan grafik penurunan medan magnet pengaruh jarak rangkaian kereta api listrik terhadap sensor ketika disimulasikan bergerak dari stasiun menuju titik tegak lurus dengan sensor magnet. Hasil perhitungan teoritis dari penurunan medan magnet terhadap jarak dapat digambarkan seperti grafik dibawah ini:

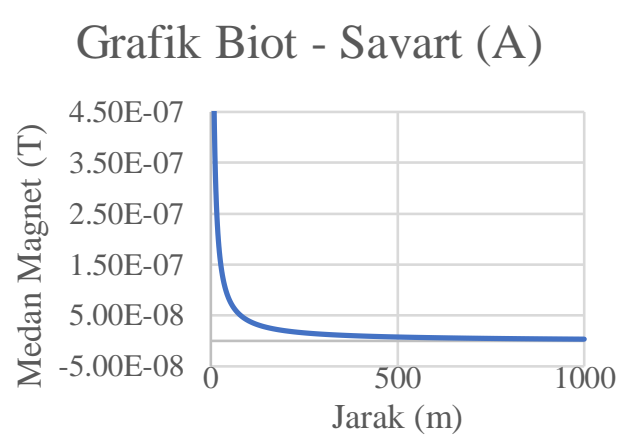

GAMBAR 14. Medan Magnet pengaruh jarak sensor

Grafik Biot - Savart A merupakan model perhitungan rumus Biot - Savart dengan kondisi posisi sensor mgnet yang secara kontinu berpindah. Kemudian grafik Biot - Savart B menggunakan perhitungan posisi gerbong kereta yang berpindah dari titik tegak lurus dari posisi sensor magnet pada jarak 340 meter sampai dengan jarak 2000 meter. Berdasarkan pada perhitungan menggunakan Hukum Biot - savart, gambar diatas menunjukkan bahwa gangguan magnetik dengan arus bocor $20 \mathrm{~A}$ memiliki gangguan sebesar $4 \mu \mathrm{T}$ pada jarak titik pengamatan sangat dekat dengan rel kereta. Nilai ini mendekati model gangguan medan magnet kereta api listrik pada penelitian Risto Pirjola pada tahun 2007. Jarak stasiun Geofisika BMKG Tangerang dengan rel kereta memiliki jarak 340 m, pada jarak ini perhitungan nilai gangguan medan magnet sebesar 11,5 nT dan pada jarak $1 \mathrm{~km}$ gangguan medan magnet sekitar 3,5 nT. 


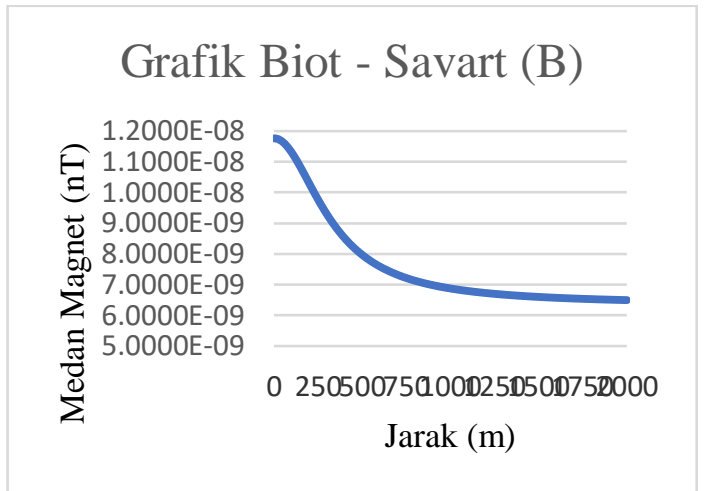

GAMBAR 15. Medan Magnet pengaruh jarak rangkaian kereta terhadap sensor.

Hasil perhitungan medan magnet pada model B menjelaskan bahwa jarak terdekat kita anggap ketika posisi rangkaian kereta tegak lurus dengan posisi sensor magnet. Pada kondisi ini prediksi nilai gangguan medan magnet maksimum sebesar 11,76 $\mathrm{nT}$ dan nilai minimum medan magnet sebesar 6,50 nT. Untuk nilai arus bocor yang berbeda-beda serta parameter yang tidak diketahui lainnya yang terkait dengan kereta DC. Perhitungannya bisa dilakukan dengan parameter input yang dikoreksi menggunakan rumus teoritis yang disajikan dalam penelitian ini. Kasus ini mungkin menjadi subjek penelitian dimasa yang akan datang.

\section{KESIMPULAN}

Penelitian ini dipresentasikan sebuah model teoritis dan rumus untuk menghitung gangguan medan magnet pada pengamatan dengan sensor yang magnet yang stasis terhadap kereta api listrik DC yang bergerak. Berdasarkan hasil penelitian gangguan magnet kereta api listrik terhadap magnet bumi, maka didapatkan beberapa kesimpulan diantaranya sebagai berikut:

1. Aktifitas kereta api listrik sangat menyebabkan gangguan yang signifikan pada pengamatan geomagnet. Diantaranya gangguan medan magnet total maksimum tercatat sebesar 27,75 nT pada pengamatan magnetik komponen $\mathrm{F}$ dan medan magnet total perhitungan teoritis sebesar 11,5 nT

2. Aktivitas gangguan magnetik mengalami penurunan gangguan pada pukul $23.00 \mathrm{WIB}-03.00 \mathrm{WIB}$

3. Gangguan medan magnet lebih besar ketika rangkaian kereta api listrik mendekati sensor magnet kemudian gangguan medan magnet terbesar terdapat ketika rangkaian kereta api listrik berada pada stasiun Tanah Tinggi

4. Medan magnet terbesar pada aktivitas kereta api listrik DC terjadi pada saat traksi awal dan ketika kedua rangkaian kereta saling berpapasan.

5. Gangguan terbesar medan magnet terjadi pada komponen magnet vertikal akibat pengaruh arus bocor ke tanah.

\section{REFERENSI}

[1] Buschow, K. H. J. dan F. R. Boer. (2004). Physics Of Magnetism and Materials. Amsterdam: Kluwer Academic Publisher.

[2] Georgescu, P., dkk.. (2002). Electric and magnetic perturbations generated by d.c. electric railway, Romania: Geofizica, Bucuresti.

[3] Gilbert, William, M. D. (1893). Lodestone and Magnetic Bodies and On The Great Magnet The Earth, diterjemahkan oleh P. Fleury Mottelay. London: Bernard Quaritch.

[4] Glaßmeier, Karl - Heinz, dkk. (2009). Geomagnetic Field Variations. Berlin: Springer.

[5] Halgamuge, Malka N., dkk.. (2010). Measurement And Analysis Of Electromagnetic Fields from Trams, Trains And Hybrid Cars. Melbourne: Radiation Protection Dosimetry, Vol. 141, No. 3.

[6] Indrawadi, Benedictus Bayu. (2017) Pengembangan Mesin Magnetic Perpetual Motion Dengan Acuan Pada Variabel Clearance Dan Sistem Overhead Camshaft. Surabaya: Institut Teknologi Sepuluh Nopember. 
[7] J. M. D. Coey. (2009). Magnetism and Magnetic Materials. New York: Cambridge University Press.

[8] Lita, Fristy. (2012). Identifikasi Anomali Magnetik Di Daerah Prospek Panas Bumi Arjuna Welirang. Depok: Unversitas Indonesia.

[9] Lowes, F. J. (2009). DC railways and the magnetik fields they produce - the geomagnetik context. Newcastle: Earth Planets Space 61, i-xv.

[10] Macmillan, Susan dan Christopher Finlay. (2014). The International Geomagnetic Reference Field: The 12th Generation. Zürich: Earth, Planet and Space

[11] Milsom, John. (2003). Field Geophysics Third Edition. London: Wiley.

[12] pádua, M. B., dkk. (2002). Disturbances on Magnetotelluric Data Due to DC Electrified Railway: A Case Study From Southeastern Brazil. Brazil: Earth Planets Space.

[13] Pemerintah Kota Tangerang. (2014). Peraturan Daerah Kota Tangerang Nomor 10 Tahun 2014 Tentang Rencana Pembangunan Jangka Menengah Daerah Kota Tangerang Tahun 2014-2018. Tangerang: Pemkot Tangerang.

[14] Pirjola, R., dkk.. (2007). Modelling the disturbance caused by a dc-electrified railway to geomagnetik measurements. Madrid: Earth Planets Space 59. 943-949.

[15] Reynolds, John M. (2011). An Introduction To Applied and Enviromental Geophysics Second Edition. United Kingdom: Wiley - Blackwell.

[16] Roy, kalyan kumar. (2007). .Potential Theory In Applied Geophysics. Calcutta: springer.

[17] Sandy, Alfhareza. (2015). Pemodelan 3D Reservoar Geothermal Berdasarkan Data Anomali Magnetik Reduction To The Pole Daerah Ulubelu Kabupaten Tanggamus. Lampung: Universitas Lampung.

[18] Santoso, Djoko. (2013). Pengantar Teknik Geofisika. Bandung: Penerbit ITB.

[19] Sugiyo, Endar Widi. (2015). Kajian Panas Bumi Daerah Medini - Gonoharjo Berdasarkan Data Geomagnetik. Semarang: Universitas Negeri Semarang.

[20] Syirojudin, Muhammad. (2010). Penentuan Karakteristik Sesar Cimandiri segmen pelabuhan ratu - Citarik Dengan Menggunakan Metode Magnet Bumi. Jakarta: Universitas Islam Negeri Syarif Hidayatullah

[21] Telford, W.M., dkk.. (1996). Applied Geophysics. United Kingdom: Cambridge University Press.

[22] Tokumoto, T and S. Tsunomura. (1984). Calculation of magnetik field disturbance produced by electric railway. Tokyo: Mem. Kakioka Maguman. Obs. 20, 2,: 33-44.

[23] William, Lowrie. (2007). Fundamental of geophysics second edition. New York: cambridge university press. 